\title{
Thymic output changes in children with clinical findings signaling a probable primary immunodeficiency
}

\author{
Neslihan Karaca ${ }^{1}$, Elif Azarsız², Sanem Eren Akarcan ${ }^{1}$, Güzide Aksu ${ }^{1}$, Necil Kütükçüler ${ }^{1}$ \\ Departments of ${ }^{1}$ Pediatric Immunology and ${ }^{2}$ Biochemistry, Ege University Faculty of Medicine, Izmir, Turkey. \\ E-mail:elif.azarsiz@ege.edu.tr \\ Received: 10th January 2018, Revised: 26th November 2018, Accepted: 13th February 2019
}

\begin{abstract}
SUMMARY: Karaca N, Azarsız E, Akarcan SE, Aksu G, Kütükçüler N. Thymic output changes in children with clinical findings signaling a probable primary immunodeficiency. Turk J Pediatr 2019; 61: 885-894.
\end{abstract}

\begin{abstract}
Thymic maturation evaluation is inevitable for patients with clinical and laboratory findings for a primary immunodeficiency, as the $\mathrm{T}$ cellimmunodeficiencies are the most severe type. In this study, we aimed to show the usage of T cell surface molecule "CD31" for the evaluation of thymic output in patients ( $\mathrm{n}: 66$ ) with a large spectrum of findings signing a probable primary immunodeficiency. Besides the classical clinical and laboratory approach for these patients, $T$ cell subpopulations as naive, memory, recent thymic emigrant cells were also investigated. The humoral immunodeficiency $(34.8 \%)$, combined immunodeficiency $(34.8 \%)$ and cardiopathy $(7.6 \%)$ were the most frequent diagnosis groups. $\mathrm{CD}^{+}{ }^{+} \mathrm{CD} 45 \mathrm{RA}^{+}$naive T-cells percentages (p: 0.011) and absolute counts (p: 0.004) and absolute $C D 4{ }^{+} \mathrm{CD} 45 \mathrm{RA}^{+} \mathrm{CD} 31^{+}$ RTE (recent thymic emigrant) cell counts (p: 0.007) were significantly lower in combined immunodeficiency group. Naive T-cells (p: 0.037) and RTE cells (p: 0.032) were also lower in patients who had cardiac surgery in the past. In conclusion, flow cytometric $\mathrm{CD} 31^{+}$thymic naive RTE cell evaluation may provide rapid clinical information especially on T-cell immune dysfunction and $\mathrm{CD} 4{ }^{+} \mathrm{CD} 45 \mathrm{RA} \mathrm{A}^{+} \mathrm{CD} 31^{+} \mathrm{RTE}$ cells may be used as an alternative to TRECs in the diagnosis of combined immunodeficiencies.
\end{abstract}

Key words: RTE, recent thymic emigrant cells, immunodeficiency.

Thymopoiesis in fetal life and the infantile period is primarily located in the thymus and develops at birth. Thymus undergoes a gradual involution by aging but preserves its main functions. The thymus is almost fully developed at birth and it reaches its maximum output during adolescence, then functional tissue transformes into adipose tissue. ${ }^{1,2}$ The main cells produced in the thymus are $\mathrm{T}$ cells and overall $\mathrm{T}$ cell levels are maintained despite thymic involution by a variety of peripheral thymus - independent homeostatic mechanisms. ${ }^{3}$

Most of the cells express a T-cell receptor composed of $\alpha$ and $\beta$ chains, but a small population expresses a receptor of $\gamma$ and $\delta$ chains. All of these chains are encoded by variable $(\mathrm{V})$, diversity (D), and junctional (J) gene segments, which are rearranged during T-cell development in a process called $\mathrm{V}(\mathrm{D}) \mathrm{J}$ recombination. After $\mathrm{T}$ cell receptor (TCR) rearrangement in these cells, extrachromosomal circles, known as T-cell receptor rearrangement excision circles (TRECs), which inform about thymic output are released into the cytoplasm. TRECs are stable DNA episomes formed during TCR rearrangement, which are not replicated and become diluted by successive cell divisions. ${ }^{4}$

Naive $\mathrm{T}$ cells, which are assumed as antigen - inexperienced after their egress from the thymus and until they are primed by foreign antigens to have been considered to express cell surface antigens, CD45RA, CD62L, CD27, CD28, and CCR7. ${ }^{5}$ In recent years, the surface molecule CD31 (PECAM-1) is suggested to be used to distinguish thymic and central naive $\mathrm{CD}^{+}{ }^{+} \mathrm{T}$-cells in the peripheral blood of healthy 
humans. ${ }^{1}$ It is a $130-\mathrm{kDa}$ transmembrane glycoprotein expressed by endothelial cells, platelets, monocytes, neutrophils, and certain $\mathrm{T}$ cell subpopulations. The post-thymic proliferation of naive $\mathrm{CD} 4{ }^{+} \mathrm{CD} 45 \mathrm{RA}{ }^{+} \mathrm{CD} 31^{+}$ T-cells, and their differentiation into memory/ effector $\mathrm{T}$ cells after interaction with foreign antigens was first suggested by Kohler et al. ${ }^{6}$ It has been shown that $\mathrm{CD} 31^{+}$naive $\mathrm{CD} 4^{+}$ T-cells have high TREC levels and are in fact recent thymic emigrant (RTE) cells. Under physiological conditions, CD31 is known to be an excellent flow cytometric marker of RTE in $\mathrm{CD}^{+}{ }^{+} \mathrm{CD} 45 \mathrm{RA}^{+}$naive $\mathrm{T}$ cells as an alternative to the direct quantification of TRECs. ${ }^{7}$ It has been demonstrated that the frequency and absolute numbers of TREC-enriched CD31+thymic naive $\mathrm{CD}^{+}{ }^{+} \mathrm{T}$-cells correlated with age in healthy persons, implying a link to the thymic function and these $\mathrm{T}$ cells are responsible for long-term T cell reconstitution. ${ }^{6} \mathrm{CD} 31$ is downregulated on about $50 \%$ of the $\mathrm{CD}^{+}$and the majority of $\mathrm{CD}^{+}{ }^{+} \mathrm{T}$-cells upon their transition to the memory phenotype. ${ }^{8}$

On the other hand, $\mathrm{CD} 31^{-}$naive $\mathrm{CD}^{+}$ T-cells are proliferated in the periphery. ${ }^{1}$ CD $4{ }^{+}$CD $45 \mathrm{RA}^{+} \mathrm{CD} 31^{-} \mathrm{T}$-cells are characterized by a drastically reduced TREC content and a restricted oligoclonal TCR repertoire, as CD31 reportedly is downregulated during homeostatic expansion of naive T-cells after ligation of the TCR with specific MHC/selfpeptide ligands.

The $\mathrm{CD}^{+}{ }^{+} \mathrm{CD} 45 \mathrm{RA}^{+} \mathrm{CD} 31^{+} \mathrm{T}$ cells display a polyclonal TCR repertoire and immunity against neoantigens. ${ }^{9}$ It has been shown that TREC content in $\mathrm{CD}^{+}{ }^{+}$T-cells and the frequencies of $\mathrm{CD} 31^{\text {thymic }}$ naive $\mathrm{CD} 4^{+}$ T-cells correlated strongly in common variable immunodeficiencyand multiple sclerosis. ${ }^{10,11}$ CD31 measurements have been also successfully used in hematopoietic stem cell and organ transplantation ${ }^{12}$, autoimmune disease $^{13}$, HIV ${ }^{14}$ and T cell abnormalities. ${ }^{10}$

In this study, we mainly evaluated the usage of CD31 $1^{\text {thymic }}$ naive cells in a patient group with clinical findings that pointed out a probable primary immunodeficiency and searched if these cells might provide any clinical information, especially on T-cell immune dysfunction.

\section{Material and Methods}

The study population consisted of 66 children who were followed by or consulted for clinical and laboratory findings with a probable primary immunodeficiency. The children with a definite diagnosis of any innate or adaptive primary immunodeficieny at admission were not included. T (-) SCID (severe combined immunodeficiency disease) patients were not included but cases with detectable/low CD3 levels and hypogammaglobulinemia with normal lymphocyte subsets, who had clinical findings indicating functional $\mathrm{T}$ cell defects were included.

All demographic information including name, gender, date of birth, age at onset of symptoms, age at admission, age at diagnosis, family history and consanguinity, clinical symptoms, complications (autoimmune disease, chronic giardiasis, granulomatosis, lymphoma or any malignancy, lymphadenomegaly, splenomegaly, bronchiectasis, musculoskeletal system findings, celiac-like disease), followup duration, and all laboratory data were recorded.

All clinical data, including immunodeficiencyrelated symptoms, signs, and complications and the laboratory investigation were evaluated. The study was approved by the ethics committee (No: 15-8/6) and no financial support was received. The written informed consent was obtained from all children or their parents before sampling for laboratory tests. Peripheral blood in EDTA was obtained from all participants. The sampling was performed 3 to 4 weeks after intravenous immunoglobulin administration if the patients were under routine therapy.

Whole blood count assay: Whole blood count for leukocyte counts, absolute neutrophil, and lymphocyte counts were performed with automated hematology analyzer (Cell-Dyn Ruby, Abbott Diagnostics, USA).

Flow cytometric analyses: The percentages and absolute counts of lymphocyte subsets which were gated based on their forward and side scatter $\left(\mathrm{CD}^{+} \mathrm{T}\right.$-cells, CD19+ $\mathrm{B}$-cells, $\mathrm{CD}^{+}{ }^{+} \mathrm{CD} 4^{+}$T-helper cells, $\mathrm{CD} 3^{+} \mathrm{CD} 8^{+}$ T-cytotoxic cells, CD $3^{+} \mathrm{HLA} \mathrm{DR}^{+}$activated $\mathrm{T}$ 
cells, CD3-CD $16^{+}{ }^{-} D 56^{+}$natural killer cells) were investigated. Special T cell subpopulations were also evaluated. T cells were stained with fluorescent conjugated monoclonal antibodies; anti-TCR- $\alpha \beta$ FITC, anti-TCR- $\gamma \delta$ PE, antiCD45RA-PE-CY5, anti-CD45RO-PE-CY5, and anti-CD31-FITC. Gating strategies were as follows; $\mathrm{CD}^{+} \mathrm{T}$ lymphocytes were gated on their forward and side scatter and CD8 ${ }^{+} \mathrm{TCR}-$ $\alpha \beta^{+}$and $\mathrm{CD} 8^{+} \mathrm{TCR}-\gamma \delta^{+} \mathrm{T}$-cells, CD $4{ }^{+} \mathrm{CD} 45 \mathrm{RA}{ }^{+}$ and $\mathrm{CD} 4+\mathrm{CD} 45 \mathrm{RO}^{+}$were analyzed. To define the naive $\mathrm{T}$ cells, $\mathrm{CD} 4^{+} \mathrm{T}$ lymphocytes were gated on their forward and side scatters. CD $4{ }^{+} \mathrm{CD}_{45 \mathrm{RA}^{+}}$cells were analyzed as the naive population and the percentage of $\mathrm{CD} 31^{+}$ cells were given as RTE cell population which was defined as $\mathrm{CD} 4{ }^{+} \mathrm{CD} 45 \mathrm{RA}^{+} \mathrm{CD} 31^{+}$cells. All analyses were performed using a FACSCalibur flow cytometer and CellQuest software (BD FlowCytometry Systems, USA).

SPSS 16 program was used for statistical analysis. One sample Kolmogorov - Smirnov test was used to check the Gaussian distribution of all variables. Statistical comparisons of numeric data were made using Student's t-test. Correlation comparisons between paired samples were made by Pearson's or Spearman product-moment correlation coefficient. MannWhitney U or Kruskal Wallis tests were used for comparisons between clinical parameters and variables. All data were expressed as mean \pm SD except when indicated otherwise. Differences between groups were considered significant at $\mathrm{p}<0.05$ value.

\section{Results}

The patient group consisted of 28 girls and 38 boys ( $\mathrm{n}$ : 66) who had been admitted to the immunology department with different complaints. The mean age of the children was $15.7+29.1$ months (range: $0-156$ ) at the onset of clinical symptoms, $29.7+40$ months (range: 0-197) at the time of admission and $37.1+45.9$ months (range: $0-240$ ) at the time of the study, respectively. A total of $28.6 \%$ of the patients was born from consanguineous parents and $28.1 \%$ had a family history.

Twenty-eight patients (43.9\%) suffered from recurrent respiratory tract infections and the other frequent clinical findings were as follows; skin rash (10.6\%), cardiopathy (7.6\%), neurological findings (7.6\%), growth retardation/no weight gain/ chronic diarrhea (6.1\%), sepsis $(6.1 \%)$, abscess/ lymphadenopathy (3.0\%), fever (4.5\%), hematological findings $(6.1 \%)$ and others (4.5\%).

In general, recurrent infection frequency was $66.2 \%$, hospitalization due to an infection was $67.2 \%$ and intensive care need was $29.7 \%$, respectively. Lower respiratory tract infections were the most frequent clinical type (55.6\%) which was followed by upper respiratory tract infections (16.7\%) and sepsis (13\%).

On physical examination, growth retardation was found in a total of $37.9 \%$ (n: 25) of the patients, organomegaly in $12.3 \%$, and genetic stigmata in $25.4 \%$ of the patients.

Demographic and general laboratory data for all patients are given in Table I. ${ }^{15,16}$ In whole patient group, immunoglobulin G, A and $\mathrm{M}$ values were low in $64.6 \%, 33.8 \%$ and $40 \%$ of the patients, consequitively. $\mathrm{CD}^{+} \mathrm{T}$-cell percentages were low in $36.4 \%$ and CD19+ B-cell percentages were low in $22.7 \%$ of the patients. $\mathrm{CD}^{+}{ }^{+} \mathrm{T}$-cell percentages correlated positively with $\mathrm{CD} 4{ }^{+} \mathrm{CD} 45 \mathrm{RA}{ }^{+} \mathrm{CD} 31^{+} \mathrm{RTE}$ cell percentages (p: 0.001, r: 0.401) and absolute counts ( $<<0.001, r: 0.588)$. Absolute RTE cell counts also showed positive correlation with CD8 ${ }^{+}$TCR- $\alpha \beta^{+}$T cells (p: 0.025, r: 0.275).

The frequencies of the disease diagnosis groups in patient populations are given in Figure 1 and the most frequent ones were humoral immunodeficiency $(34.8 \%)$, combined immunodeficiency $(34.8 \%)$ and cardiopathy $(7.6 \%)$ groups. "Other disease group" consisted of two patients with sepsis, one patient with Wilson disease, one patient with hyperimmunoglobulin E syndrome and one patient with immunodysregulation syndrome. In Table II, the most frequent groups' laboratory data and the comparisons are summarized. $\mathrm{CD}^{+}{ }^{+} \mathrm{CD} 45 \mathrm{RA}^{+}$naive T-cell percentages (p: 0.029) and absolute counts (p: 0.003) showed statistically significant difference between these three groups. When the most frequent two diagnosis groups, humoral and combined immunodeficiencies were compared, $\mathrm{CD}_{4}{ }^{+} \mathrm{CD} 45 \mathrm{RA}^{+}$naive $\mathrm{T}$-cell 
Table I. The Demographic and General Laboratory Data for Patients.

\begin{tabular}{|c|c|c|}
\hline Features & Results** & Reference range \\
\hline Age at time of study, months & $37.1 \pm 45.9$ & - \\
\hline Age at onset of symptoms, months & $15.7 \pm 29.1$ & - \\
\hline Age at admission, months & $29.7 \pm 40.0$ & - \\
\hline Leukocyte count, $\mathrm{mm}^{3}$ & $12,500 \pm 6,913$ & $4,000-10,400^{*}$ \\
\hline Absolute lymphocyte count, $\mathrm{mm}^{3}$ & $4,889 \pm 3,102$ & $1,500-5,200^{*}$ \\
\hline Immunoglobulin G (IgG), mg/dl & $604 \pm 384$ & $737-1,051$ \\
\hline Immunoglobulin A (IgA), mg/dl & $53 \pm 78$ & $49.8-94.1$ \\
\hline Immunoglobulin M (IgM), mg/dl & $103 \pm 188$ & $57.1-127$ \\
\hline \multirow[t]{2}{*}{ CD19+ B-cells, \% (/mm3) } & $24.8 \pm 16.6$ & $11-31^{*}$ \\
\hline & $(1,111 \pm 852)$ & $(300-1,200)^{*}$ \\
\hline \multirow[t]{2}{*}{$\mathrm{CD}^{+}$T-cells, \% (/mm3) } & $58.6 \pm 16.8$ & $55-79^{*}$ \\
\hline & $(3,047 \pm 2,429)$ & $(1,900-3,600)^{*}$ \\
\hline \multirow[t]{2}{*}{$\mathrm{CD}^{+} 4^{+} \mathrm{T}$-helper cells, $\%\left(/ \mathrm{mm}^{3}\right)$} & $33.1 \pm 14.6$ & $26-49^{*}$ \\
\hline & $(1,724 \pm 1,556)$ & $(600-2,000)^{*}$ \\
\hline \multirow[t]{2}{*}{$\mathrm{CD}^{+}{ }^{+}{ }^{+}$T-cytotoxic cells, $\%\left(/ \mathrm{mm}^{3}\right)$} & $21.8 \pm 12.8$ & $9-35^{*}$ \\
\hline & $(1,147 \pm 1,333)$ & $(300-1,300)^{*}$ \\
\hline \multirow[t]{2}{*}{ CD3-16 $56^{+}$natural killer cells, $\%\left(/ \mathrm{mm}^{3}\right)$} & $13.6 \pm 9.69$ & $5-28^{* *}$ \\
\hline & $(620 \pm 633)$ & $(200-1,200)^{*}$ \\
\hline \multirow[t]{2}{*}{$\mathrm{CD}^{+}{ }^{+} \mathrm{HLA} \mathrm{DR}^{+}$active $\mathrm{T}$ cells, $\%\left(/ \mathrm{mm}^{3}\right)$} & $10.6 \pm 14.6$ & - \\
\hline & $(602 \pm 1,262)$ & - \\
\hline \multirow[t]{2}{*}{$\mathrm{CD}^{+}{ }^{+} \mathrm{CD} 45 \mathrm{RA}^{+}$naive T-cells, $\%\left(/ \mathrm{mm}^{3}\right)$} & $44.9 \pm 20.0$ & $20-41^{*}$ \\
\hline & $(1,401 \pm 1,309)$ & $(500-6,600)^{*}$ \\
\hline \multirow[t]{2}{*}{$\mathrm{CD}^{+}{ }^{+} \mathrm{CD} 45 \mathrm{RO}^{+}$memory T-cells, $\%\left(/ \mathrm{mm}^{3}\right)$} & $16.8 \pm 1.60$ & $8-42^{*}$ \\
\hline & $(688 \pm 934)$ & $(200-800)^{*}$ \\
\hline \multirow[t]{2}{*}{ 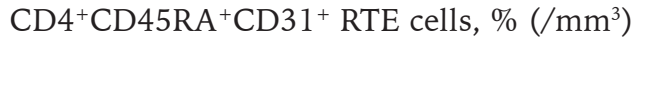 } & $51.2 \pm 21.9$ & $64^{* * *}$ \\
\hline & $(988 \pm 1,015)$ & - \\
\hline \multirow[t]{2}{*}{ CD8 ${ }^{+}$TCR- $\alpha \beta^{+}$T-cells, , $\%\left(/ \mathrm{mm}^{3}\right)$} & $32.0 \pm 14.2$ & - \\
\hline & $(1,016 \pm 1,168)$ & - \\
\hline \multirow[t]{2}{*}{ CD8 ${ }^{+} \mathrm{TCR}-\gamma \delta^{+} \mathrm{T}$-cells, $\%\left(/ \mathrm{mm}^{3}\right)$} & $4.82 \pm 7.13$ & - \\
\hline & $(103 \pm 143)$ & - \\
\hline
\end{tabular}

*: Reference 15 (Turkish Journal of Pediatrics 2004; 46: 125-130.)

**: Data is presented as mean \pm standard deviation

***: Reference 16 for median value (Cytometry B Clin Cytom. 2019; 96: 223-233.)

percentages (p: 0.011) and absolute counts ( $\mathrm{p}$ $=0.004)$ showed a significant difference again. $\mathrm{CD}^{+}{ }^{+} \mathrm{CD} 45 \mathrm{RA}^{+} \mathrm{CD} 31^{+}$RTE cell percentages showed no significant difference between these groups (p: 0.231 ) but the absolute counts of RTE cells (p: 0.007) were significantly lower in the combined immunodeficiency group.
CD8 ${ }^{+}$TCR- $\alpha \beta^{+}(\mathrm{p}=0.015)$ and CD8 ${ }^{+}$TCR$\gamma \delta^{+} \quad(\mathrm{p}=0.024) \quad \mathrm{T}$-cell absolute counts showed significant difference between the main three disease groups but this difference was not significant (p: 0.144, p: 0.974) especially between humoral and combined immunodeficiency groups. 


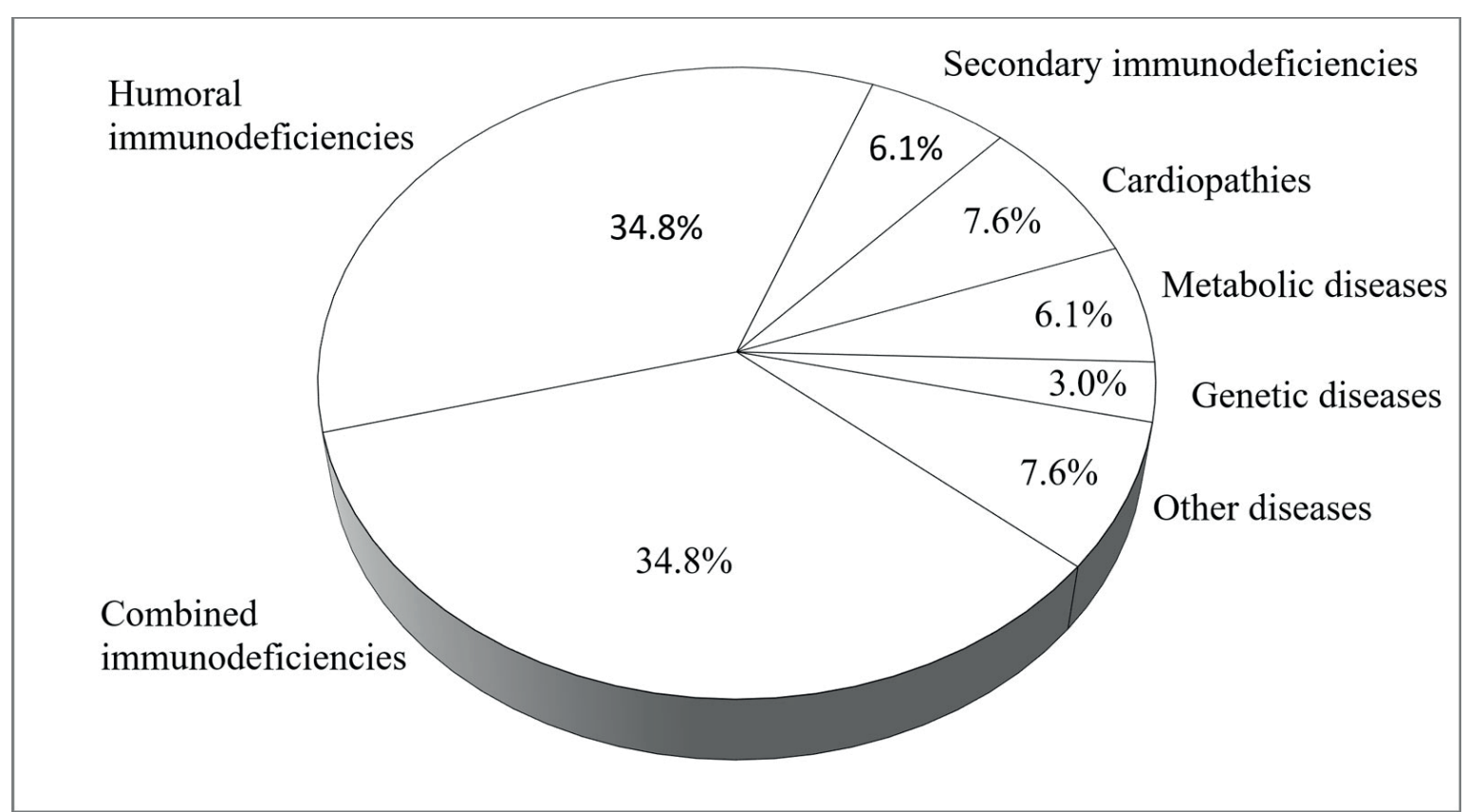

Fig. 1. The frequencies of the different disease diagnosis groups.

At least one cardiac pathology was observed in $36.9 \%$ (n: 24) of the patients. Eight of these patients had corrective cardiac surgery in the past. Table III summarized the laboratory data and the comparisons for these patients. Naive CD4 ${ }^{+}$CD45RA ${ }^{+}$T-cells (p: 0.037) and $\mathrm{CD}^{+} \mathrm{CD} 45 \mathrm{RA}^{+} \mathrm{CD} 31^{+}$RTE cells (p: 0.032) were lower in the operated group and the difference was statistically significant.

One patient had subtotal and two patients had total thymectomy in the past. $\mathrm{CD} 4{ }^{+} \mathrm{CD} 45 \mathrm{RA}^{+} \mathrm{CD} 31^{+}$naive $\mathrm{T}$ cell percentages (p: 0.166 ) or absolute values (p: 0.243) did not show any statistically significant difference between patient groups according to thymectomy $(+/-)$ because of the small number of patients.

The mean percentage of naive $\mathrm{CD}^{+}$ T-cells and RTE cells in different clinical manifestations are summarized in Table IV. Neither naive CD4 ${ }^{+}$T-cells (p: 0.385) nor RTE cells (p: 0.653) showed statistically significant difference according to autoimmune clinic presentation. Patients with lymphadenopathy had significantly lower naive $\mathrm{CD} 4^{+} \mathrm{T}$-cells ( $\mathrm{p}$ : 0.012).

In the study group, haemopoietic stem cell transplantation had been performed in two patients with Omenn syndrome and $\mathrm{T}^{-} \mathrm{B}^{-} \mathrm{NK}^{+}$
SCID. In the combined immunodeficiency patient group, naive CD4 ${ }^{+} \mathrm{T}$-cells (p: 0.275), RTE cells (p: 0.113), CD $8^{+}$TCR- $\alpha \beta^{+}$T-cells (p: 0.743 ) and $\mathrm{CD} 8^{+} \mathrm{TCR}-\gamma \delta^{+} \mathrm{T}$-cells (p: 0.059) showed no statistically significant difference according to HSCT.

\section{Discussion}

Primary immunodeficiencies are a heterogeneous group of disorders with an increased susceptibility to infections. The more sophisticated tools are researched to accelerate the diagnosis year after year. Besides a general approach for these patients, thymic maturation evaluation has a great importance every time as the $\mathrm{T}$ cell-immunodeficiencies are the most severe type and early diagnosis and HSCT are life-saving for these patients. ${ }^{17}$

In this study group, patients showed a large spectrum of complaints and also recurrent infections and hospitalization frequencies were quite high. A total of $43.9 \%$ of the patients had suffered from recurrent respiratory tract infections and $75.4 \%$ of the patients had showed low values for at least one of the serum immunoglobulins. The detailed physical examination and laboratory data for immunodeficiencies oriented the clinical diagnosis in the whole group. 
Table II. Comparison of Laboratory Data of the Patients Groups with Most Frequently Observed Diagnosis.

\begin{tabular}{|c|c|c|c|c|}
\hline Parameters & $\begin{array}{c}\text { Humoral } \\
\text { immunodeficiencies } \\
\text { (n: 23) }\end{array}$ & $\begin{array}{c}\text { Combined } \\
\text { immunodeficiencies } \\
(\mathrm{n}: 23)\end{array}$ & $\begin{array}{l}\text { Cardiopathy } \\
\text { alone } \\
\text { (n: } 5)\end{array}$ & $\mathrm{p}$ value \\
\hline Age at the time of the study, months & $37.3 \pm 33.6$ & $46 \pm 59$ & $8.40 \pm 6.26$ & 0.128 \\
\hline Age at onset of symptoms months & $18.8 \pm 24.3$ & $17.9 \pm 37.5$ & $0.40 \pm 0.89$ & $0.009 *$ \\
\hline Age at admission months & $31.1 \pm 31.5$ & $35.1 \pm 49.5$ & $3.40 \pm 3.78$ & $0.018^{*}$ \\
\hline Leukocyte count, $/ \mathrm{mm}^{3}$ & $13,700 \pm 7,932$ & $12,700 \pm 6,488$ & $8,112 \pm 2,453$ & 0.148 \\
\hline Absolute lymphocyte count, $/ \mathrm{mm}^{3}$ & $5,265 \pm 2,059$ & $4,981 \pm 3,521$ & $2,664 \pm 1,032$ & 0.065 \\
\hline Immunoglobulin G (IgG), mg/dl & $447 \pm 330$ & $771 \pm 442$ & $482 \pm 183$ & $0.013^{*}$ \\
\hline Immunoglobulin A $(\operatorname{Ig} A), \mathrm{mg} / \mathrm{dl}$ & $43 \pm 52$ & $70.5 \pm 110$ & $21.2 \pm 9.80$ & 0.880 \\
\hline Immunoglobulin $\mathrm{M}(\mathrm{IgM}), \mathrm{mg} / \mathrm{dl}$ & $76 \pm 77$ & $168 \pm 296$ & $23.8 \pm 7.49$ & $0.010^{*}$ \\
\hline \multirow[t]{2}{*}{ CD19+ B-cells, \% (/mm³) } & $23.7 \pm 14.5$ & $25.5 \pm 19.0$ & $30.4 \pm 23.3$ & 0.830 \\
\hline & $(1,248 \pm 909)$ & $(1,139 \pm 956)$ & $(928 \pm 906$ & 0.759 \\
\hline \multirow[t]{2}{*}{$\mathrm{CD}^{+}$T-cells, $\%\left(/ \mathrm{mm}^{3}\right)$} & $63.0 \pm 12.6$ & $58.3 \pm 18.7$ & $38.8 \pm 20.2$ & 0.059 \\
\hline & $(3,306 \pm 1,526)$ & $(3,202 \pm 2,964)$ & $(915 \pm 479)$ & $0.007^{*}$ \\
\hline \multirow[t]{2}{*}{$\mathrm{CD}^{+} 4^{+}$T-helper cells, $\%\left(/ \mathrm{mm}^{3}\right)$} & $34.9 \pm 12.6$ & $32.6 \pm 18.0$ & $22.8 \pm 10.8$ & 0.157 \\
\hline & $(1,906 \pm 1,161)$ & $(1,654 \pm 1,840)$ & $(572 \pm 350)$ & $0.013^{*}$ \\
\hline \multirow[t]{2}{*}{$\mathrm{CD}^{+}{ }^{+}{ }^{+}$T-cytotoxic cells, $\%\left(/ \mathrm{mm}^{3}\right)$} & $22.5 \pm 11.5$ & $22.7 \pm 16.5$ & $15.2 \pm 11.8$ & 0.373 \\
\hline & $(1,135 \pm 664)$ & $(1,394 \pm 1,986)$ & $(323 \pm 181)$ & $0.008^{*}$ \\
\hline \multirow{2}{*}{$\begin{array}{l}\text { CD3-16 } 56^{+} \text {natural killer cells, \% (/ } \\
\left.\mathrm{mm}^{3}\right)\end{array}$} & $12.1 \pm 9.45$ & $12.8 \pm 8.48$ & $25.8 \pm 11.7$ & 0.057 \\
\hline & $(664 \pm 608)$ & $(518 \pm 438)$ & $(691 \pm 403)$ & 0.630 \\
\hline \multirow{2}{*}{$\begin{array}{l}\mathrm{CD}^{+}{ }^{+} \mathrm{HLA} \mathrm{DR}^{+} \text {active T-cells, } \% \\
\left(/ \mathrm{mm}^{3}\right)\end{array}$} & $7.91 \pm 8.35$ & $17.2 \pm 21.3$ & $7.40 \pm 8.38$ & 0.057 \\
\hline & $(413 \pm 532)$ & $(1,057 \pm 1,942)$ & $(137 \pm 118)$ & 0.118 \\
\hline \multirow{2}{*}{$\begin{array}{l}\mathrm{CD}^{+}{ }^{+} \mathrm{CD} 45 \mathrm{RA}^{+} \text {naive T-cells, } \% \\
\left(/ \mathrm{mm}^{3}\right)\end{array}$} & $49.8 \pm 17.5$ & $34.6 \pm 20.3$ & $51.6 \pm 23.6$ & $0.029 *$ \\
\hline & $(1,747 \pm 1,183)$ & $(1,029 \pm 1,208)$ & $(521 \pm 440)$ & $0.003^{*}$ \\
\hline \multirow{2}{*}{$\begin{array}{l}\mathrm{CD}^{+}{ }^{+} \mathrm{CD} 45 \mathrm{RO}^{+} \text {memory T- cells, } \% \\
\left(/ \mathrm{mm}^{3}\right)\end{array}$} & $19.9 \pm 7.75$ & $32.1 \pm 20.0$ & $39.8 \pm 29.3$ & 0.068 \\
\hline & $(636 \pm 368)$ & $(886 \pm 1,473)$ & $(310 \pm 268)$ & 0.114 \\
\hline \multirow{2}{*}{$\begin{array}{l}\mathrm{CD}^{+}{ }^{+} \mathrm{CD} 45 \mathrm{RA}^{+} \mathrm{CD} 31^{+} \mathrm{RTE} \text { cells, } \% \\
\left(/ \mathrm{mm}^{3}\right)\end{array}$} & $72.9 \pm 16.9$ & $64.5 \pm 23.8$ & $57.8 \pm 30.4$ & 0.406 \\
\hline & $(1,362 \pm 1,028)$ & $(773 \pm 1,037)$ & $(8,378 \pm 412)$ & $0.007^{*}$ \\
\hline \multirow[t]{2}{*}{ CD $8{ }^{+}$TCR- $\alpha \beta^{+}$T-cells, $\%\left(/ \mathrm{mm}^{3}\right)$} & $29.7 \pm 12.4$ & $34.4 \pm 17.1$ & $30.6 \pm 19.1$ & 0.547 \\
\hline & $(969 \pm 573)$ & $(1,267 \pm 1,735)$ & $(294 \pm 182)$ & $0.015^{*}$ \\
\hline \multirow[t]{2}{*}{ CD $8^{+}$TCR- $\gamma \delta^{+}$T-cells, $\%\left(/ \mathrm{mm}^{3}\right)$} & $3.13 \pm 2.26$ & $7.00 \pm 9.61$ & $3.20 \pm 1.30$ & 0.816 \\
\hline & $(89 \pm 53)$ & $(147 \pm 215)$ & $(30 \pm 17.1)$ & $0.024 *$ \\
\hline
\end{tabular}

(Student t test, Kruskal Wallis test; ${ }^{*} \mathrm{p}<0.05$ )

As the TREC-enriched CD31 ${ }^{\text {thymic }}$ naive $\mathrm{CD} 4^{+}$ T-cells implies a link to the thymic function ${ }^{6}$ we determined the $\mathrm{CD} 4{ }^{+} \mathrm{CD} 45 \mathrm{RA}{ }^{+} \mathrm{CD} 31^{+}$ RTE cell frequencies in patients for thymic evaluation. It has been shown that the TREC content in $\mathrm{CD} 31^{+} \mathrm{CD} 45 \mathrm{RA}^{+} \mathrm{RO}-\mathrm{CD} 4{ }^{+} \mathrm{T}$ cells was on average 18 times higher than in $\mathrm{CD} 31^{-}$
CD45RA+RO-CD4 ${ }^{+}$lymphocytes. ${ }^{18}$ As an excellent cellular marker for human thymic activity, the cytometric analysis of these cells may be easily standardized and is performed in a short time. The mean $\mathrm{CD} 4{ }^{+} \mathrm{CD} 45 \mathrm{RA}^{+} \mathrm{CD} 31^{+}$ RTE cell frequency was $51.2 \pm 21.9 \%$ in our patients, but we cannot comment on this value 
Table III. The Laboratory Data of the Patients with a Cardiac Pathology.

\begin{tabular}{|c|c|c|c|}
\hline & $\begin{array}{l}\text { Operated } \\
\text { (n: } 8)\end{array}$ & $\begin{array}{l}\text { Not operated } \\
\text { (n 16) }\end{array}$ & $\mathrm{p}$ value \\
\hline \multirow[t]{2}{*}{$\mathrm{CD}^{+}$T-cells, \% $\left(/ \mathrm{mm}^{3}\right)$} & $41.2 \pm 16.3$ & $60.7 \pm 19.2$ & $0.037^{*}$ \\
\hline & $(1,150 \pm 791)$ & $(3,435 \pm 2,905)$ & $0.032^{*}$ \\
\hline \multirow[t]{2}{*}{$\mathrm{CD}^{+} 4^{+} \mathrm{T}$-helper cells, $\%\left(/ \mathrm{mm}^{3}\right)$} & $26.6 \pm 10.5$ & $39.1 \pm 15.4$ & 0.08 \\
\hline & $(774 \pm 602)$ & $(292 \pm 1,818)$ & $0.050^{*}$ \\
\hline \multirow[t]{2}{*}{$\mathrm{CD}^{+}{ }^{+} \mathrm{CD} 45 \mathrm{RA}^{+}$naive T-cells, $\%\left(/ \mathrm{mm}^{3}\right)$} & $45.3 \pm 15.7$ & $54.1 \pm 21.9$ & 0.18 \\
\hline & $(583 \pm 530)$ & $(1,997 \pm 1,730)$ & $0.037^{*}$ \\
\hline \multirow[t]{2}{*}{$\mathrm{CD}^{+}{ }^{+} \mathrm{CD} 45 \mathrm{RO}^{+}$memory T-cells, $\%\left(/ \mathrm{mm}^{3}\right)$} & $34.1 \pm 21.7$ & $28.8 \pm 19.9$ & 0.41 \\
\hline & $(308 \pm 186)$ & $(751 \pm 591)$ & 0.098 \\
\hline \multirow[t]{2}{*}{$\mathrm{CD}^{+}{ }^{+} \mathrm{CD} 45 \mathrm{RA}^{+} \mathrm{CD} 31^{+} \mathrm{RTE}$ cells, $\%\left(/ \mathrm{mm}^{3}\right)$} & $49.1 \pm 17.4$ & $67.9 \pm 17.8$ & $0.011^{*}$ \\
\hline & $(345 \pm 397)$ & $(1,426 \pm 1,306)$ & $0.032^{*}$ \\
\hline \multirow[t]{2}{*}{$\mathrm{CD}^{+} 8^{+}$T-cytotoxic cells, $\%\left(/ \mathrm{mm}^{3}\right)$} & $13.8 \pm 7.24$ & $19.5 \pm 8.95$ & 0.37 \\
\hline & $(346 \pm 213)$ & $(1,087 \pm 1,007)$ & $0.032 *$ \\
\hline \multirow[t]{2}{*}{ CD8 ${ }^{+}$TCR- $\alpha \beta^{+}$T-cells, $\%\left(/ \mathrm{mm}^{3}\right)$} & $28.2 \pm 12.3$ & $29.4 \pm 11.8$ & 0.83 \\
\hline & $(305 \pm 173)$ & $(988 \pm 888)$ & $0.032 *$ \\
\hline \multirow[t]{2}{*}{ CD8 ${ }^{+}$TCR- $\gamma \delta^{+}$T-cells, $\%\left(/ \mathrm{mm}^{3}\right)$} & $3.62 \pm 3.15$ & $3.25 \pm 5.10$ & 0.19 \\
\hline & $(36.0 \pm 24.5)$ & $(95 \pm 124)$ & 0.18 \\
\hline
\end{tabular}

(Student $\mathrm{t}$ test, Mann Whitney U test; ${ }^{*} \mathrm{p}<0.05$.)

Table IV. The Mean Percentages of Naive CD4+ T-cells and RTE Cells in Different Clinical Manifestations.

\begin{tabular}{lcccccc}
\hline \multicolumn{2}{l}{ Clinical manifestation } & $\begin{array}{c}\text { Number of } \\
\text { patients }\end{array}$ & $\begin{array}{c}\text { Naive CD4 } \\
\text { T cells, } \%\end{array}$ & p & RTE cells, \% & p \\
\hline Autoimmunity & Yes & 8 & $38.3 \pm 21.4$ & 0.39 & $62.1 \pm 25.8$ & 0.65 \\
& No & 58 & $45.8 \pm 20.0$ & & $67.4 \pm 20.1$ & \\
Organomegaly & Yes & 8 & $32.7 \pm 27.0$ & 0.10 & $65.3 \pm 20.4$ & 0.64 \\
& No & 58 & $46.6 \pm 18.7$ & & $67.0 \pm 27.9$ & \\
Lymphadenopathy & Yes & 6 & $24.1 \pm 16.2$ & 0.012 & $72.3 \pm 14.4$ & 0.63 \\
& No & 60 & $47.0 \pm 19.4$ & & $66.2 \pm 21.2$ & \\
\hline
\end{tabular}

due to the lack of a healthy control group. But, CD4 ${ }^{+}$T-cell percentages correlated with CD4 ${ }^{+}$CD $45 \mathrm{RA}^{+} \mathrm{CD} 31^{+}$RTE cells (p: 0.001, r: 0.401) and absolute RTE cell counts correlated with CD8 ${ }^{+}$TCR $-\alpha \beta^{+}$T cells (p: 0.025, r: 0.275).

In the literature, some studies on the role of RTE cells in primary immunodeficiencies are present. Guazzi et al. ${ }^{19}$ had observed significantly reduced TREC levels both in $\mathrm{CD}^{+}$ and in $\mathrm{CD}^{+}$T-cell compartments of CVID patients compared with those of age-matched healthy controls suggesting a reduction of thymic output in CVID individuals. But it was unclear whether the damage of the $\mathrm{T}$ cell compartment was related to an altered generation of new $\mathrm{T}$ cells from hematopoietic stem cells or to a defect in thymic and/or bone marrow compartment. Isgro et al. ${ }^{10}$ studied the TREC content in CD4 ${ }^{+}$T-cells and showed that the frequencies of $\mathrm{CD} 31^{+ \text {thymic }}$ naive $\mathrm{CD} 4^{+}$ T-cells correlated strongly in CVID. Oraei et al. $^{20}$ has also shown a decline in thymic output in CVID patients compared to healthy controls and showed lower naive $\mathrm{CD} 4^{+} \mathrm{T}$-cell and $\mathrm{CD}_{3} 1^{+}$naive RTE cell values in male patients. Bateman et al. ${ }^{21}$ also found that absolute numbers of recent thymic emigrants 
were significantly decreased in CVID and the reduction was particularly in patients with polyclonal lymphoproliferation, autoimmune cytopenias, and organ-specific autoimmune disease. As we evaluated our patients, they most frequently belonged to humoral immunodeficiency $(34.8 \%)$, combined immunodeficiency $(34.8 \%)$ and cardiopathy (7.6\%) groups. The $\mathrm{CD}^{+}{ }^{+} \mathrm{CD} 45 \mathrm{RA}^{+}$naive T-cell percentages (p: 0.029) and absolute counts (p: 0.003) showed statistically significant difference between these three groups. When the most frequent two diagnosis groups, humoral and combined immunodeficiencies, were compared, $\mathrm{CD}^{+}{ }^{+} \mathrm{CD} 45 \mathrm{RA}^{+}$naive $\mathrm{T}$-cell percentages ( $p:$ 0.011) and absolute counts (p: 0.004) showed significant difference again. The $\mathrm{CD}^{+} \mathrm{CD} 45 \mathrm{RA}^{+} \mathrm{CD} 31^{+}$RTE cell percentages showed no significant difference between these groups ( $\mathrm{p}:$ 0.231) but the absolute counts (p: 0.007) were significantly lower in combined immunodeficiency group (Table II). Together with the reduced $\mathrm{CD}^{+}$ naive T-cells, reduced thymic emigrants in the combined immunodeficiency group suggested a lack of replenishment of the $\mathrm{CD}^{+}{ }^{+} \mathrm{T}$-cell pool by new thymically derived cells in these patients.

$\mathrm{CD} 8^{+} \mathrm{TCR}-\alpha \beta^{+}(\mathrm{p}=0.015)$ and $\mathrm{CD} 8^{+} \mathrm{TCR}-\gamma \delta^{+}$ $(\mathrm{p}=0.024) \mathrm{T}$-cell absolute counts showed a significant difference between the main three disease groups but this difference was not significant especially between humoral and combined immunodeficiency groups (p: 0.144 , p: 0.974, respectively).

We evaluated the naive $\mathrm{CD}^{+}{ }^{+} \mathrm{T}$-cell and RTE cell compartment alterations in different clinical manifestations; autoimmunity, lymphadenopathy, organomegaly. Oraei et al. ${ }^{20}$ had observed autoimmune manifestations in patients with low naive CD4 ${ }^{+} \mathrm{T}$-cells and RTE cells in CVID and speculated that autoimmunity might be related to lower thymic output in CVID. In autoimmunity, $T$ cells respond to an antigenic challenge by clonal burst, therefore reduce the peripheral levels of TRECs. Neither naive $\mathrm{CD}^{+}{ }^{+} \mathrm{T}$-cells nor RTE cells showed a statistically significant difference according to autoimmune clinic presentation in the whole study group (Table IV) or in humoral immunodeficiency group. CD $8^{+} \mathrm{TCR}-\gamma \delta^{+} \mathrm{T}$-cell values were slightly higher in patients with autoimmune manifestations but the difference was not statistically significant.

It has been shown that partial thymectomy is common during cardiothoracic surgery in children. In the study group, at least one cardiac pathology was observed in $36.9 \%(n=24)$ of the patients and eight of them had a corrective cardiac surgery in the past. Naive $\mathrm{CD} 4^{+} \mathrm{T}$-cells (p: 0.037) and RTE cells (p: 0.032) were lower in the operated group and the difference between the operated and non-operated group was statistically significant (Table III). Kurobe et al. ${ }^{22}$ studied the cellularity of circulating lymphocytes and T-cell-mediated immune responses in patients with congenital heart defects who had thymectomy early in life at 0-3 months. They showed a decreased T-cell number in completely thymectomized patients and they suggested to preserve at least a portion of thymus during surgery.

Many studies have established that neonatal thymectomy reduces the subsequent number of circulating $\mathrm{T}$ cells. Eysteinsdottir et al. ${ }^{23}$ showed significantly lower counts of $\mathrm{CD}^{+}$ and $\mathrm{CD}^{+}{ }^{+}$-cells and made a conclusion as in thymectomized patients there was a shift to extrathymic T-cell maturation which was less efficient for $\mathrm{CD}^{+}$cells and the clinical effects of neonatal thymectomy remained unclear. The mean $\mathrm{CD}^{+}$and $\mathrm{CD}^{+}{ }^{+} \mathrm{T}$-cell percentages were also lower in our thymectomized patients. Madhok et al. ${ }^{24}$ studied the effect of partial thymectomy on TREC values. They showed that TRECs had significantly declined in patients in the immediate post-operative period and TREC values in the patient group without thymectomy were higher than the patients who had a partial thymectomy. Halnon et al. ${ }^{25}$ showed markedly reduced TRECs values in patients many years after thymectomy in childhood, concurrently with decreases in total $\mathrm{T}$ cells and naive $\mathrm{CD} 4^{+}$ T-cells. Patients with no residual thymus had significantly lower TRECs than those with partial thymectomy and they speculated that partial thymectomy and decrease in TRECs did not influence immune function because there were no known autoimmune diseases over follow up. The minimal residual thymic tissue was sufficient for immune function. In a meta-analysis made by Roosen et al. ${ }^{26}$, it was suggested that the thymectomy was 
responsible for immunological alterations, reduced proportions of RTE and lower numbers of naive $\mathrm{T}$ cells. van Gent et al. ${ }^{27}$ described the impact of thymectomy during early childhood over three decades; so the presence of new TREC-containing naive $T$ cells was suggestive of thymic regeneration. Patients with absent thymi, such as in SCID or in complete DiGeorge syndrome have very low TREC levels. Two patients with DiGeorge Syndrome in our patient group had no thymus. One patient had subtotal and two patients had total thymectomy in the past. Patients with no residual thymus had significantly lower naive $\mathrm{CD}^{+}{ }^{+} \mathrm{T}$-cell and RTE cells than those with partial thymectomy. Neither $\mathrm{CD}^{+}{ }^{+} \mathrm{CD} 45 \mathrm{RA}^{+} \mathrm{CD} 31^{+}$RTE cell percentages nor absolute values showed a statistically significant difference between patients according to thymectomy because of a small number of groups.

RTE cells may also give information about thymic functions after HSCT. Greinix et al. ${ }^{12}$ suggested that elevated $\mathrm{CD} 4{ }^{+} \mathrm{CD} 45 \mathrm{RA}{ }^{+} \mathrm{CD} 31^{+}$ $T$ cells on day 100 after allogeneic hematopoietic cell transplantation was a useful predictive marker for diagnosing chronic graft-versushost disease. They had also speculated that TREC quantification emerged as an important assay for monitoring T-cell neogenesis after transplantation and high TREC levels ensured engraftment and prevented infection. Junge et al. ${ }^{18}$ had shown that in lymphopenic children during 12 months after myeloablative HSCT the majority of reemerging $\mathrm{CD} 4{ }^{+} \mathrm{CD} 45 \mathrm{RA}{ }^{+} \mathrm{RO}-$ T-cells expressed CD31. In this study group, HSCT was performed in two patients, one with Omenn syndrome and one with $\mathrm{T}^{-} \mathrm{B}^{-} \mathrm{NK}^{+}$SCID. We could not compare the cell distribution individually according to HSCT cure and also could not find any difference in combined immunodeficiency patients according to HSCT cure. In combined immunodeficiency group, naive $\mathrm{CD}^{+}{ }^{+} \mathrm{T}$-cells, RTE cells, CD8 ${ }^{+} \mathrm{TCR}-\alpha \beta^{+}$ T-cells and CD8 ${ }^{+} \mathrm{TCR}-\gamma \delta^{+} \mathrm{T}$-cells showed no statistically significant difference.

The utility of TREC assay has been proved as a tool for neonatal screening for SCID. ${ }^{28,29}$ Evaluation of thymic maturation is essential in patients having a broad spectrum of symptoms that preoccupy a probable primary immunodeficiency. Taking together all clinical and laboratory findings, flow cytometric CD31 $1^{\text {thymic }}$ naive RTE cell evaluation may provide rapid clinical information especially on T-cell immune dysfunction. In conclusion, CD $4{ }^{+} \mathrm{CD} 45 \mathrm{RA}^{+} \mathrm{CD} 31^{+}$RTE cells may be used as an alternative to TRECs in the diagnosis of combined immunodeficiencies and it could also be used as a prognostic marker for immune competence in general. But more studies are needed in isolated diagnosis groups such as T-cell positive leaky functional defects.

\section{REFERENCES}

1. Kimmig S, Przybylski GK, Schmidt CA, et al. Two subsets of naive $\mathrm{T}$ helper cells with distinct $\mathrm{T}$ cell receptor excision circle content in human adult peripheral blood. J Exp Med 2002; 195: 789-794.

2. Boehm T, Swann JB. Thymus involution and regeneration: two sides of the same coin? Nat Rev Immunol 2013; 13: 831-838.

3. Harris JM, Hazenberg MD, Poulin JF, et al. Multiparameter evaluation of human thymic function: interpretations and caveats. Clin Immunol 2005; 115 : 138-146.

4. Hazenberg MD, Verschuren MC, Hamann D, Miedema F, van Dongen JJ. T cell receptor excision circles as markers for recent thymic emigrants: basic aspects, technical approach, and guidelines for interpretation. J Mol Med (Berl) 2001; 79: 631-640.

5. De Rosa SC, Herzenberg LA, Herzenberg LA, Roederer M. 11-color, 13-parameter flow cytometry: identification of human naive $\mathrm{T}$ cells by phenotype, function, and T-cell receptor diversity. Nat Med 2001; 7: 245-248.

6. Kohler S, Thiel A. Life after the thymus: CD31+ and CD31- human naive CD4+ T-cell subsets. Blood 2009; 113: 769-774.

7. Junge S, Kloeckener-Gruissem B, Zufferey R, et al. Correlation between recent thymic emigrants and $\mathrm{CD} 1^{+}$(PECAM-1) $\mathrm{CD}^{+} \mathrm{T}$ cells in normal individuals during aging and in lymphopenic children. Eur J Immunol 2007; 37: 3270-3280.

8. Stockinger H, Schreiber W, Majdic O, Holter W, Maurer D, Knapp W. Phenotype of human T cells expressing CD31, a molecule of the immunoglobulin supergene family. Immunology 1992; 75: 53-58.

9. Kohler S, Wagner U, Pierer M, et al. Post-thymic in vivo proliferation of naive $\mathrm{CD} 4+\mathrm{T}$ cells constrains the TCR repertoire in healthy human adults. Eur J Immunol 2005; 35: 1987-1994.

10. Isgro $\mathrm{A}$, Marziali $\mathrm{M}$, Mezzaroma I, et al. Bone marrow clonogenic capability, cytokine production, and thymic output in patients with common variable immunodeficiency. J Immunol 2005; 174: 5074-5081. 
11. Duszczyszyn DA, Beck JD, Antel J, et al. Altered naive CD4 and CD8 $\mathrm{T}$ cell homeostasis in patients with relapsing-remitting multiple sclerosis: thymic versus peripheral (non-thymic) mechanisms. Clin Exp Immunol 2006; 143: 305-313.

12. Greinix HT, Kuzmina Z, Weigl R, et al. CD19+CD21low $B$ cells and CD4+CD45RA + CD31+T cells correlate with first diagnosis of chronic graft-versus-host disease. Biol Blood Marrow Transplant 2015; 21: 250-258.

13. Armengol MP, Sabater L, Fernandez M, et al. Influx of recent thymic emigrants into autoimmune thyroid disease glands in humans. Clin Exp Immunol 2008; 153: $338-350$

14. Douek DC, McFarland RD, Keiser PH, et al. Changes in thymic function with age and during the treatment of HIV infection. Nature 1998; 396: 690-695.

15. Ikinciogulları A, Kendirli T, Dogu F, et al. Peripheral blood lymphocyte subsets in healthy Turkish children. Turk J Pediatr 2004; 46: 125-130.

16. Garcia-Prat M, Alvarez-Sierra D, Aguilo-Cucurull A, et al. Extended immunophenotyping reference values in a healthy pediatric population. Cytometry B Clin Cytom 2019; 96: 223-233.

17. Somech R. T-cell receptor excision circles in primary immunodeficiencies and other T-cell immune disorders. Curr Opin Allergy Clin Immunol 2011; 11: 517-524.

18. Junge S, Kloeckener-Gruissem B, Zufferey R, et al. Correlation between recent thymic emigrants and CD31+ (PECAM-1) CD4 $+\mathrm{T}$ cells in normal individuals during aging and in lymphopenic children. Eur J Immunol 2007; 37: 3270-3280.

19. Guazzi V, Aiuti F, Mezzaroma I, et al. Assessment of thymic output in common variable immunodeficiency patients by evaluation of $\mathrm{T}$ cell receptor excision circles. Clin Exp Immunol 2002; 129: 346-353.

20. Oraei M, Aghamohammadi A, Rezaei N, et al. Naive CD4 + T cells and recent thymic emigrants in common variable immunodeficiency. J Investig Allergol Clin Immunol 2012; 22: 160-167.
21. Bateman EA, Ayers L, Sadler R, et al. T cell phenotypes in patients with common variable immunodeficiency disorders: associations with clinical phenotypes in comparison with other groups with recurrent infections. Clin Exp Immunol 2012; 170: 202-211.

22. Kurobe $\mathrm{H}$, Tominaga $\mathrm{T}$, Sugano $\mathrm{M}$, et al. Complete but not partial thymectomy in early infancy reduces T-cell-mediated immune response: three - year tracing study after pediatric cardiac surgery. J Thorac Cardiovasc Surg 2013; 145: 656-662.

23. Eysteinsdottir JH, Freysdottir J, Haraldsson A, et al The influence of partial or total thymectomy during open heart surgery in infants on the immune function later in life. Clin Exp Immunol 2004; 136: 349-355.

24. Madhok AB, Chandrasekran A, Parnell V, Gandhi M, Chowdhury D, Pahwa S. Levels of recent thymic emigrant cells decrease in children undergoing partial thymectomy during cardiac surgery. Clin Diagn Lab Immunol 2005; 12: 563-565.

25. Halnon NJ, Jamieson B, Plunkett M, Kitchen CM, Pham T, Krogstad P. Thymic function and impaired maintenance of peripheral $\mathrm{T}$ cell populations in children with congenital heart disease and surgical thymectomy. Pediatr Res 2005; 57: 42-48.

26. Roosen J, Oosterlinck W, Meyns B. Routine thymectomy in congenital cardiac surgery changes adaptive immunity without clinical relevance. Interact Cardiovasc Thorac Surg 2015; 20: 101-106.

27. van Gent R, Schadenberg AW, Otto SA, et al. Longterm restoration of the human T-cell compartment after thymectomy during infancy: a role for thymic regeneration? Blood 2011; 118: 627-634.

28. Routes JM, Grossman WJ, Verbsky J, et al. Statewide newborn screening for severe T-cell lymphopenia. JAMA 2009; 302: 2465-2470.

29. Thakar MS, Hintermeyer MK, Gries MG, Routes JM, Verbsky JW. A practical approach to newborn screening for severe combined immunodeficiency using the $\mathrm{T}$ cell receptor excision circle assay. Front Immunol 2017; 8: 1470 . 